\title{
LETTER FROM THE EDITOR
}

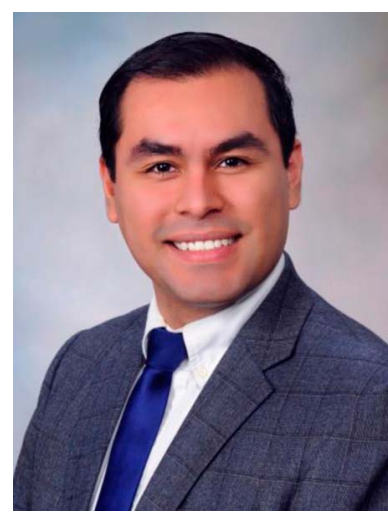

\section{Behind the Case: An ACG Case Reports Journal Podcast}

Today's society is more mobile than ever, and we expect to access a world of information wherever we are. ${ }^{1}$ Podcasts are audio-media files that can be accessed on-demand via the Internet and played on any hand-held devices or computer at any time and in any place. ${ }^{2}$ Multiple medical journals have begun creating their own podcasts, many of which are successful and sustainable. Medical journal podcasts can reach different audiences who may not be able to read the journal every month, and an interview-based podcast can attract the peer group or following of the interviewee as well. ${ }^{3,4}$

Behind the Case: An ACG Case Reports Journal Podcast was created to expand the reach and impact of the journal, to give our trainee editors and trainee interviewees an opportunity to develop their podcasting and interview skills. Moreover, we hope that the podcast will increase the journal's value to its readers because it provides another platform for learning interesting cases.

Podcasts are an important communication and education platform that continues to grow. For example, Apple podcasts had 2 billion reproductions in 2005 , a number that increased tremendously to 50 billion in 2018 . There are over 750,000 podcasts series, comprising more than 30 million episodes. There is no surprise that over $50 \%$ of the U.S. population has listened to at least one podcast. Interestingly, $50 \%$ of listening is done at home and $25 \%$ is done while driving a car, and $70 \%$ of podcast listening is done from a smartphone. In medical education, podcasts are effective in promoting learning and retention of the listeners. There is scientific evidence on this effectiveness; for example, a randomized controlled trial found that medical students in groups listening to podcasts earned higher scores in their test compared with a control group who just used a traditional textbook. ${ }^{5}$

Episodes of Behind the Case will feature interviews of authors of noteworthy cases published in ACG Case Reports Journal, who will discuss in-depth details of the case. We hope to stimulate you to read the article, and we will do our best to cover interesting teaching points during our conversations. We are confident that our podcast will not only teach you something new about a case or topic but will also entertain you!

We hope you enjoy the Behind the Case podcast, and we welcome you to tune in, learn, and be entertained, all while supporting GI trainees. Please go to gi.org/acgcrpodcasts to listen or subscribe on iTunes, Google Podcasts, Stitcher, Pocket Casts, or Spotify.

C. Roberto Simons-Linares, MD, MSc

Gastroenterology and Hepatology Department, Digestive Diseases Institute, Cleveland Clinic Foundation, Cleveland, OH

Editor-in-Chief \& Podcaster

ACG Case Reports Journal

\section{REFERENCES}

1. Choi AR, Tamblyn R, Stringer MD. Electronic resources for surgical anatomy. ANZ J Surg. 2008;78(12):1082-91.

2. Chen Z, Melon J, Evolution of social media: Review of the role of podcasts in gynaecology. Int Urogynecol J. 2018;29(4):477-80.

3. Min AA, Morley EJ, Rezaie SR, Fox SM, Grock A. Academic life in emergency medicine blog and podcast watch: Respiratory emergencies. Cureus. 2018;10(6):e2812.

4. Wilson P, Petticrew M, Booth A, After the gold rush? A systematic and critical review of general medical podcasts. J R Soc Med. 2009;102(2):69-74.

5. Back DA, von Malotky J, Sostmann K, Hube R, Peters H, Hoff E. Superior gain in knowledge by podcasts versus text-based learning in teaching orthopedics: A randomized controlled trial. J Surg Educ. 2017;74(1):154-60.

Copyright: ๑ 2019 The Author(s). Published by Wolters Kluwer Health, Inc. on behalf of The American College of Gastroenterology. This is an open-access article distributed under the terms of the Creative Commons Attribution-Non Commercial-No Derivatives License 4.0 (CCBY-NC-ND), where it is permissible to download and share the work provided it is properly cited. The work cannot be changed in any way or used commercially without permission from the journal. 